\title{
The Regulation on Village Governance in Indonesia: Efficient Contracting in Agency Theory
}

\author{
Fandi Galang Wicaksana (Corresponding Author) \\ Student in Accounting Master, Faculty of Economics and Business \\ Sebelas Maret University, Surakarta, Indonesia \\ E-mail: fandigalang0908@gmail.com
}

\begin{abstract}
R. Agus Trihatmoko
Doctor of Management, Faculty of Economics, and Graduate Study Program

University of Surakarta, Surakarta, Indonesia

E-mail: agustricentre@gmail.com
\end{abstract}

\begin{abstract}
Djoko Suhardjanto
Professor of Accounting, Faculty of Economics and Business

Sebelas Maret University, Surakarta, Indonesia

E-mail: djoko.suhardjanto@yahoo.com

Henny Murtini

Accounting Master, Faculty of Economics and Business

Semarang State University, Semarang, Indonesia

E-mail: hennymurtini@gmail.com
\end{abstract}

Received: April 25, 2019 Accepted: May 20, 2019 Online published: May 21, 2019

doi:10.5296/jpag.v9i2.14812 URL: https://doi.org/10.5296/jpag.v9i2.14812

\begin{abstract}
The application of efficient contracting concept in Village Fund management is an interesting idea and formula in the public governance perspective. The concept provides a potential solution so that the Village Government obey the Law No. 6 of 2014 and brings impact to
\end{abstract}


public-oriented service. The philosophical concept of "Gotong Royong” or mutual assistance reinforces the efficient contracting essence. The aim of this research is to build a framework of public governance on Village Fund by implementing the efficient contracting, and to identify, illustrate and describe the variables in efficient contracting concept to Village Fund Management. The research used qualitative method, designed in narrative strategy and grounded theory approach, and formulated using constructivism paradigm. Results of the study have demonstrated that (1) Efficient contracting concept encompasses economic constitution, government policy, public finance management and governance, also the functional relationship in the government body (Central, Regional and Village); (2) the essence of Efficient Contracting is the community active participation, legal aspect, government attention, balance consensus, effectiveness and efficiency, justice and equality, transparency, responsibility and accountability. The descriptive findings were interpreted in textual and structural method to expand the Efficient Contracting concept and to bring implication in development administration and public management.

Keywords: agency theory, efficient contracting, economic constituent, government policy, public management and public governance, village governance

\section{Introduction}

The paradox in public funds expenditure has been a subject to debate implied in the term efficient contracting in public organization. To date, the essence of the contract based on law (see, Atiyah, 1996) is difficult to be implemented in public organization (in this case, the government) due to some contributing factors. Battese and Coelli (1995), Stevens (2004), Boyne (2003), and Stanislaus, Damayanti and Syamsuddin (2017) reported that political intrigue potentially obstructs the government's endeavour in undertaking an efficient contract. It may occur because a consensus is established among the bureaucratic agents which eventually indicates a misuse of public funds - an evident violation of law. Misuse of public funds may include budget slack, kleptocracy and budget distortion (Stanislaus et al., 2017). In agency perspective, the tendency to misconduct is the manifestation of self interest (see, Boyne, 2003); a deviant administrative behavior by spending public funds for self-gratification. The prevalence of misuse is naturally affecting the accuracy of information on Government economic transaction embodied in the financial report as a form of public accountability (Bovens, 2006; Iyoha and Oyerinde, 2010). Accordingly, the citizens need to invest time in observing public affairs (see, Stiglitz, 2003) when the policy makers are held responsible for their misconduct in order to avoid waste of public funds and, the worst case, corruption. In light of the prevalent misconduct in government body, it is important to conduct a study on the essence of efficient contracting. The study is focused in the context of public funds management based on legal term. It is expected that public funds are well managed and spent by the government according to the declared vision.

Studies on public expenditure have been conducted in many countries; however, the majority has not explored how to formulate the ideal solution for the aforementioned issues in efficient contracting. Afonso, Schuknecht, and Tanzi (2005), Ammons and Rivenbark (2008), and Widodo (2017) investigated the effect of stability, allocation and distribution of public 
expenditure as a step towards efficiency in 23 OECD countries, North Carolina and Indonesia, respectively. However, the majority of literature in the early 21 st century focus on the role of institutional regulation in privatisation of public sector through collaboration with private sector in the UK, Australia, Ukraine and Africa (see, Coram, 2006; Boyne, 2003; Akhlaghi, 1996; Hensher, Billon, Macário, Preston, White, Tyson, Van de Velde, Wee, Aragão, Santos, and Filho, 2007; Ng and Loosemore 2007; Kraan, Trapp, Kostyleva, Tuinen, and Morgner, 2013; Mchopa 2015). Furthermore, Battese and Coelli (1995) observed the characteristics of different concepts in districts in India such as how far the political process affects the government efficiency. However, the present study will investigate the contract that can be readily used by the principal agent as the executor of efficient contracting (see, Jensen and Meckling, 1976; Lane, 1999) towards a better public service.

It is the fundamental vision of the government to establish community welfare through public service (Rhodes, 1996). In practical context, Bourgon (2007) elaborated three pivotal points for the Government to prosper the people: (1) respect the law, (2) commit to serve public interest, and (3) expect the civil servants to exercise integrity, honesty and neutrality in maintaining public trust. This condition affects the government's perspective as the driving force of a country in determining the correct paradigm for development. Negara Kesatuan Republik Indonesia (NKRI) or Republic of Indonesia exercises different perspective to address the paradigm.

The current paradigm of Indonesian government as the new face of economic constitution includes Village Fund program run in "Gotong Royong" or mutual assistance participation. Village Fund programme aims to improve welfare and empowerment of village community. The government's mission is to allocating funding to be managed by the Village Government themselves (Data of Village Funds is presented in Table 1 in appendices). This paper is a further study as suggested by Simangunsong and Wicaksono (2017) on the importance of accountability in managing public finance in Village Funds program in Indonesia. The public funds here refer to Village Fund Allocation (VFA) of Regional Budget (APBD) and Village Fund (VF) allocated from the State Budget (APBN) that is guided by the Law No. 6 of 2014 on Villages and Ministry of Home Affairs Regulation No 113 of 2014 on Village Financial Management (VFM). The conception has motivated the researcher to review the role of Village Law in the context of public governance. Therefore, the focus of this research is to disclose the contract of principal relationship and government sub-agent in an attempt to understand the essence of Village Law.

Simangunsong and Wicaksono (2017) reported that the constitution law that regulates Village Fund program is guided by the Law of Republic Indonesia No. 6 of 2014 or referred as Village Law. Based on the law in Indonesia, Village Law is a policy for regulating the authority in Village Government. The villages receive additional funding in form of VF which is directly managed by the Village Government solely to increase the prosperity and empowerment of the Village community. However, recent studies on VF program by Salim, Bulan, Untung, Laksono, and Brock (2017) and Ash-shidiqqi and Wibisono (2018) reported a concern that VF as additional funding would contribute more burden to Village financial administration where the operational system is underpinned by the state finance systems and 
regulation. Furthermore, the stakeholders are concerned about the danger of potential misconduct - administrative and management - on VF by the village officials (Afifah, Kartini, and Yuningsih, 2017; Temenggung, 2016). Data on Village Chiefs who have committed corruption and misconduct on VF program are presented in Figure 1 and Table 2 of the appendices.

On the other hand, Indonesian citizens expect the government to run a good governance by implementing the government governance principle by Organization for Economic Cooperation and Development (OECD, 2016). OECD stated that implementing good public governance will stimulate the creation of government programs and agenda that are oriented to the people. In Village Fund context, the community is at the receiving end of empowerment based on the objectives of Village Law (the main principle); therefore, the obligation of Village Government (sub-agent) over accountability, transparency and responsibility (ATR) is targeted beyond the District Head as the Head of Regional Government (the main agent). In fact, the ATR of Village Government is only targeted to the District Head instead of the community. The main issue is raised: what is the essence of Village Law in light of public governance? Therefore, the aim of this study is to establish public governance framework on Village Fund through the implementation of efficient contracting in agency theory.

The operational of the research objective is conducted by illustrating the framework surrounding public governance through in-depth identification, description and investigation into the Regulation of Village Governance which has been indicated as the formula of efficient contracting. This explorative research did not investigate the legality of agency contract between the government principal agent and sub-agent to scrutinize the chapters of Village Law and the Ministry of Home Affairs Regulation No. 113 of 2014 that have been reviewed and adjusted to the OECD principles. Accordingly, the policy objectives and the essence of the contents of the constitution are made known.

\section{Literature Review}

To date, Village Fund management has been a concern to many stakeholders. The focus is on the various misuses of public fund committed by the village officials. It serves as a warning for the government to be responsive to such case. This condition has put pressure on the government across levels-Central, Provincial and Regional-to implement the proper strategy in stewarding and supervising the Village officials to obey the law, to commit to serving public interest, and to encourage them to practise integrity, honesty and neutrality in maintaining public trust (e.g., Bourgon, 2007); in this case, Village Fund management. The program may be delivered by giving an understanding on financial management and governance in order to accomplish good public governance.

In theory, the Village Government is expected to uphold efficiency in good public governance on Village Fund. The essence of efficiency is based on the agency theory - the State and/or the community as the main principal, the government as the main agent and the Village Government as the sub-agent (see, Trihatmoko and Susilo, 2018). In functional relationship context, the House of Representative Indonesia bestows an authority to the Regional 
Government to foster and supervise Village Government. The application of this agency theory is through the law-binding principal-agent contract that is undertaken based on mutual understanding and agreement (Lane, 1999; Jensen and Meckling, 1976; Atiyah, 1996; Jehn, 1997).

In practice, Lane (1999) explained that efficient contracting in public organization is a series of contract between the principal (government) and the agent (CEO) implemented in the coordination mechanism of work relationship and the clarification of objectives and obligation to public service. Public service may be delivered in expenditure of goods and service or national infrastructure construction (Schick, 1998). When the government or the agents (CEO) - known as the government agents that include regional government and sub-agent Village Government (see, Trihatmoko and Susilo, 2018)—allocated budget for public goods and service or infrastructure expenditure through the contract, they use the contract in the context of Penal Law (see, Atiyah, 1996) where the contract substance is an obligation for the government in accordance with the applicable law. Furthermore, Jehn (1997) stated that the contract secured a guarantee for the stakeholders to conduct the role and obligation in responsible manner.

In the context of the study, the lexical meaning of efficient contracting is an agreement between the principal (the District Head and the people) and sub-agent (Village Government) which is bound by the regulations of Village Governance, based on gotong royong to run the management of Village Funds and aimed to improve community welfare. It is important to know that the participation pattern of gotong royong is the underpinning ideology and culture of Indonesian Republic. Gotong Royong contributes specifically to every government program and initiative; therefore, in a writing on customary law raising a topic Contemporary Indonesia, gotong royong considered a cultural operator (Bowen, 1986). In the cultural context of Village Funds management, gotong royong is defined as a moral obligation to help each other in developing the village and to actively participate in the government in order to establish a dynamic and harmonious village that upholds communal interest.

Considering the contractual issues i.e. asymmetric information conducted by the bureaucratic agent in government body (see, Lane, 1999; Battese and Coelli, 1995; Stevens, 2004; Stanislaus et al., 2017), efficient contracting is aimed to providing the best outcome for the principles instead of maximizing mutual utilities of both the principles and the agents (Bergen, Dutta and Walker, 1992). The best outcome targets three main points by Bourgon (2007), and thus indirectly affect the behaviour of village officials to be more efficient and effective in harnessing public resources, improving accountability, focusing on output and improving performance (see, Hood, 1991, 1995). It is the embodiment of good public governance.

Agency theory analizes the contractual structure so that the agents would perform and behave according to the principle's expectation (Jensen and Meckling, 1976; Lane, 1999). Contract agreement in this contect is the power delegation to the sub-agent of Village Government to conduct activities related to funding management in this case Village Funds i.e. VFA and VF according to the responsibility carried by the Village Law. Village Law contains some 
chapters on basic principles according to OECD such as the role of community participation, the role of legal aspect, government attention, a balanced consensus, effectiveness and efficiency, justice and equality, transparency, responsibility and accountability (OECD, 2016). Village Government as the government sub-agents have to understand the perspective of those principles in order to hold accountability over their performance to the central government i.e. the House of Representative, the District Head and the community. Therefore, efficient contracting is expected to be understood and implemented by the related stakeholders especially the village officials.

This literature review indicates that the variables of public governance which carry nine OECD principles as mentioned in the chapters of Village Law and the Ministry of Home Affairs Regulation No. 113 of 2014 are the formula of efficient contracting. The main concern is to investigate the principle variables in OECD version according to the Village Law and the Ministry of Home Affairs Regulation No. 113 of 2014. It is structure of development administration and public management for Village Government. The general question of this research is "what is the essence of Village Law and the Ministry of Home Affairs Regulation No. 113 of 2014 in light of public governance principles?'

Furthermore, how the present study will investigate (1) the format of agency contract of public fund management i.e. VFA and VF according to nine OECD principles, (2) the themes description of OECD principles in the chapters on the regulation of village governance, and (3) the structural description of efficient contracting in Village Fund management.

Perspective conceptualisation for the literature review above is explained in the framework of efficient working contract between the government principles and the sub-agents as presented in Figure 1. The framework serves as the knife and guideline for analysis in qualitative research (Fatchan, 2011; Saldana, 2011; Creswell, 2013) namely to identify, to describe, and to understand the efficient contracting between the government principal and sub-agents in light of the implementation of the Village Law and the Ministry of Home Affairs Regulation No. 113 of 2014.

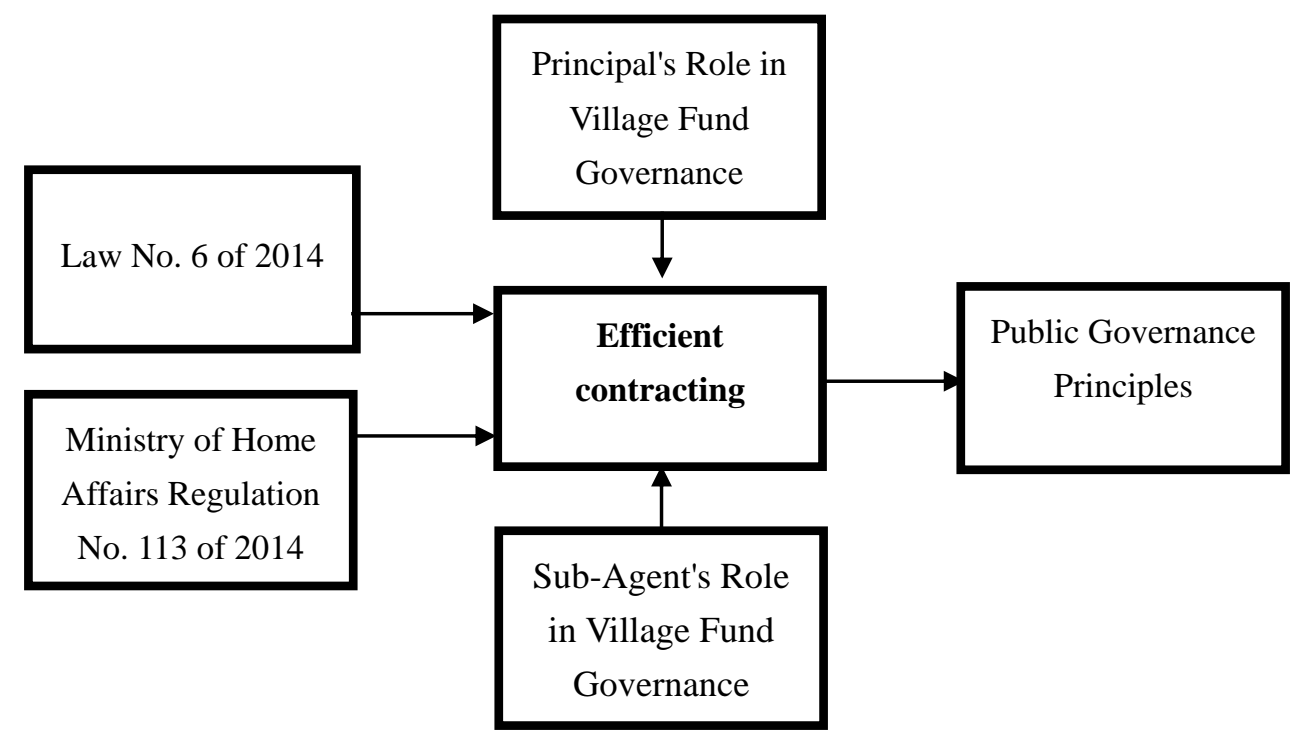

Figure 1. Efficient contracting model between the government principal and sub-agent 
Source: Jensen and Meckling (1976), Lane (1999), Law No. 6 of 2014 on Village Fund Management.

\section{Research Method}

The research used qualitative method applying narrative strategy and grounded theory approach formulated in constructivism paradigm (Creswell, 2009; Creswell, 2013; Adele, Frisie, and Wasburn, 2015; Fatchan, 2011). Narrative strategy was implemented to unfold the fundamentals of efficient contracting, while grounded theory approach was used to collect the theories into the construction of efficient contracting (Adele et al., 2015).

The narrative strategy and grounded theory approach (see, Creswell, 2013; Adele et al., 2015; Trihatmoko and Susilo, 2018) are explained as follows: (1) narrative strategy focuses on the narration and story of the object being discussed about Efficient Contracting in public governance, i.e. the management and governance of Village Fund which is investigated by combing the laws surrounding the issues; (2) grounded theory approach focuses on the analysis of an Efficient Contracting phenomenon and thus creating a new specific theory on Village Fund management; (3) constructivism paradigm is the data interpretation based on the chapters in the Village Law and the Ministry of Home Affairs Regulation No. 113 of 2014 applying descriptive approach to the management principles of OECD. Accordingly, the procedure for narrative strategy, grounded theory approach and constructivism paradigm has been applied to form a set of strategy to solve the questions of this research.

Data analysis applied a comprehensive procedural approach which elaborates Efficient Contracting in textual and structural method (Creswell, 2013; Gupta and Awasthy, 2015; Taylor, Bodgan, and DeVauldt, 2016; Trihatmoko and Susilo, 2018). Furthermore, data validation followed the procedure of persistent observation and data interpretation analysis (Creswell, 2013). The researcher also performed an open discussion or interview with the academics of Village Public Governance in a Mini Focus Group Discussion (MFGD). Persistent observation is conducted by investigating the raw and regulation related to Village Fund. To date, there is no emerging applicable laws on the issue except the Ministry of Home Affairs Regulation No 113 of 2014 that has been revised into the Ministry of Home Affairs Regulation No 20 of 2018. Data interpretation analysis is conducted to establish credibility, and interview-discussion in MFGD forum aims to find the compatibility between the variables of Efficient Contracting and the chapters in the Village Law and the Ministry of Regulation No. 113 of 2014 (Creswell, 2013).

\section{Results and Discussion}

\subsection{Textual Description and Theme Description}

Textual description is based on the themes in efficient contracting of Village Fund management using the OECD version such as The Role of Community Participation, Legal Aspect, the Government Attention, Balanced Consensus, Effectiveness and Efficiency, Justice and Equality, Transparency, Responsibility and Accountability. The topics is presented in conjunction with the underlying principles, regulation on Village governance and the related literature on VFM. To ease the identification process on the chapters in two regulations, the 
researcher applied coding system as follows:

Note: (*) regulation based on the Law No. 6 of 2014

(**) regulation based on the Ministry of Home Affairs Regulation No. 113 of 2014

\subsection{Identifying the Essence of Regulation on Village Government}

The result of the study identified the essential topic on village governance according to nine OECD principles to build a conceptual framework of efficient contracting as presented in Table 3. Efficient contracting includes economic constitution, government policy (Central, Regional and Village), public governance, and functional relationship between the governments (Central, Regional and Village). Each topic is described in textual and structural method based on data processing and analysis in form of chapters in the Village Law and Ministry of Home Affairs Regulation No. 113 of 2014, which is subject to discussion in Mini Focus Group Discussion (MFGD) and constructive interpretation to interlink the variables. The topic on the table emerged evenly in the description of the Village Law but appeared otherwise in the Ministry of Home Affairs Regulation No. 113 of 2014. The difference is because the focus of the latter regulation is on Village Financial Management. Further discussion will highlight the principles in the study.

\subsubsection{Community Active Participation}

The community have the freedom to speak, to associate and to actively participate, either directly or indirectly (through an institution), in supporting Village development for the sake of community welfare. It has been stated in the Village Law as follows:

"The community is obliged to participate in every activity in the village." (Article 68 Section $\left.2 \mathrm{e}^{*}\right)$

The article describes that the community plays a role or "Gotong Royong" in developing the village, and actively participates in running the village governance such as the Village Forums. In practical context, the community participation is actualized in initiatives or movement to develop Village potentials and assets.

\subsubsection{Legal Aspect}

Legal regulation is upheld in government administration, including budgeting, to avoid detrimental violation to the country. Indonesia is a law state where all forms of government administration are based on the applicable law.

"The principle of legal certainty is the principle of a law state that upholds constitution, obedience and justice in all policies ..." (Article 24 Para a*)

Furthermore, violation of law leads to a sanction according to the applicable law. Accordingly, legal force is the most important factor in supporting Village fund management that is free from Corruption, Collusion and Nepotism (CCN). Legal aspect is the underlying principle for government administration in all levels (Central, Regional and Village). Therefore, in village level, the role of state and regional government (provincial and district) in stewardship and 
supervision would direct a law-abiding Village governance, thus establishing transparency and accountability in Village Financial Management.

\subsubsection{The Government Attention}

The government plans and provides need-based services and empowerment-physical and non-physical - to all related stakeholders, especially the community. In delivering the service, the Village Government has provided expenditure allocation as expressed in Village Government Work Plan (RKP Desa).

"Service and empowerment are the Village Government's attempt to improve the standard of living and welfare of the village community through the implementation of policies, programs and activities in the corridor of essential issues and priority needs of the village community." (Articles 3 para $1^{*}$ )

"expenditure group for service and empowerment is described in RKP Desa." (Article 13 Section $\left.2^{* *}\right)$

Public service is defined as the embodied attention from the Village Government to the Village community. The main objective of public service is the embodiment of a higher social welfare by the fulfilment of community's life necessities. The regulation has been expressed in the Village Law Article 4 para f. Public service may include physical aspect (infrastructure) or non-physical aspect (education, health and others).

\subsubsection{Balanced Consensus}

Governance bridges the diversity of community interests to establish the overall consensus. The overall consensus is obtained when the entire community aspiration is delivered to the government. It is facilitated by the Village Forums where all village officials, Village Consultative Agency (BPD) and the village community assemble. Village Forums is regulated in the Ministry of Home Affairs Regulation No. 66 of 2007 on Village Development Planning. Specifically, the Village Law Article 54 regulates BPD. Elucidation of Article 54 has clearly explained that the result of BPD will be the performance guideline for the Village Government and other institution.

The aim of Village Forums is to set a priority needs/to discuss the obstacles in implementing Village Fund of the previous year as the guideline for preparing RKP Desa. In the process, Azlina, Hasan, and Muda (2017) explained that the issues in the village-including several budgets and priority development program - are suggested by the village delegation team in Village Forums Sub-district. Accordingly, the Sub-district Head will select the program based on the Village needs. When the programs are approved, the delegation team will present the regional issue in District Village Forums in the finalization of RKP Desa. Village Government, according to the Ministry of Home Affairs Regulation No. 113 of 2014 Article 20 Section (3) suggests Village Regulation for Village Budget (APBDesa) to the BPD and Sub-district Head that have been discussed and based upon mutual agreement. 


\subsubsection{Effectiveness and Efficiency}

The government and government agency manage public resources effectively and efficiently for the community welfare. This regulation has been described in Village Law Article 24 para $\mathrm{h}$ as follows:

"Effectiveness implies that all activities must reach the expected goal for the Village community. On the other hand, efficiency decides that every activity must be conducted according to planning and objectives."

Effectiveness and efficiency are closely related to the operations of Village finance i.e. VFA and VF. The ideal village financial operations involve human resource potentials in the village classified as adequate, competent and professional. The selected human resources are expected to run the village financial operations according to planning, so the programs and activities funded by VFA and VF to avoid waste of budgeting and specifically reach the goal in Village Law Article 24 para i. The goal is to highlight the local wisdom of each region. Local wisdom is closely related to the natural resources of the Village. When human resource can maximize the utilization of natural resources, it is expected to see the gradual improvement in economy and welfare of the village community. To support the utilization of village natural resources to support economy and welfare, Village Government has established RKP Desa.

\subsubsection{Justice and Equality}

A balance distribution of rights and obligation for both Village Government and the community through the implementation of authority and funding is based on objective and fair deliberation. A balance of rights and obligation is aimed to direct the embodiment of APBDesa (VFA and VF) according to the needs of the community. Furthermore, early participation is expected to obtain the embodiment of community rights and obligation; therefore, the community will have the sense of belonging and independence to developing the village. Accordingly, the Village Law Article 24 para c is fulfilled:

"The administration of Village Government upholds the communal welfare is an aspirational manner."

When conflict of interest occurs, the village community has the authority to address the Village Chief. Village Law Article 68 Section (1) para c stated that the village community has the authority of supervision over the village administration in form of aspiration, suggestion and opinion.

\subsubsection{Transparency}

Openness and responsibility are delivered by the government in orderly, timely and reliable manner to the related stakeholders, particularly the BPD and the community. The community has the rights to receive information regarding VFM from budget planning to budget realization in form of report.

"The Village Chief is responsible to the BPD in reporting and disseminating written 
information to the community about the government administration annually as a form of undertaking the duty, authority, rights and obligations as the Head of Government in Village level." (Article 27 para c and para $\mathrm{d}^{*}$ )

In this context, the report refers to a report on VFM. The Village Chief is obliged to not withhold information from the community and to exercise transparency-including the budget amount - in managing the finance for public expenditure such as goods/service expenditure and infrastructure construction. In line with Village Law Article 82 Section (4), the Village Government is obliged to disseminate not only VFM Report but also information on the planning and implementation of Village Medium Term Development Plan (RPJM Desa), RKP Desa, and APBDesa. It is the required openness and obligation from the Village Government. Basically, the report is discussed in Village Forums at least once a year with the BPD and the community. Moreover, the government also disseminate information to other readily-accessed services.

\subsubsection{Responsibility}

Responsibility refers to the responsibility to mandate, delegate authority or bestow a duty to a government official to optimize the resources in reaching the vision and mission. The task is given to the central and regional government to the Village Government through stewardship and supervision. When undertaking the stewardship task, the government empowers the village community as follows:

"Disseminate knowledge on developing education and technology; and Provide education, training and extension to improve the quality of the government and the community;

"The program is given to the Village Government with the stewardship of BPMPD (Community Development and Village Governance Agency at Provincial and District level) for planning, implementing and supervising the Development of Village and Rural Area" (Article 112 Section 3 and Section 4*)

In addition to providing stewardship, the government also supervise the Village development through the Village Information System or Regional Inspectorate. The development of Village information system or commonly known as Village Financial Information System (Siskuedes) - accorrding to the mandate of Village Law Article 86 Section 2 and 3. The aim of Siskuedes is to present data to avoid misuse by the Village Government and to provide the community with an easy access to Village finance information.

\subsubsection{Accountability}

The obligation to disseminate and report all activities and program on financial administration to the leader. Accountability refers to the control perspective over the organization behaviour to reach the goal. The process starts from the village officials and BPD who comprehend the Village Law and other regulation. Furthermore, the village official must be able to conduct recording, reporting and accountability. The essence of accountability is basically the willpower to perform improvement, perfection and 
responsibility according to the applied regulation. Accountability is implemented through VFM activity that has been regulated in Village Law. The Village Law present VFM in form of a report on development and government administration to the District Head (Article 27 para $\mathrm{a}^{*}$ ), BPD (Article 27 para $\mathrm{c}^{*}$ ), and community (Article 27 para $\mathrm{d}^{*}$ ).

\subsection{Structural Description}

The structural description of this paper is based on the aforementioned textual description. Theoretical framework is established to build the concept of Efficient Contracting in public governance, so the researcher proposed research premise and proposition $(\mathrm{Pa}, \ldots$ per topic and P1-P15 respectively). The order of discussion on structural descriptive principles is done systematically.

\subsubsection{Justice and Equality}

Premise

Pa: Justice and equality exist because the community rights and obligation to channel their aspiration in supporting the village development are well-received

$\mathrm{Pb}$ : Community aspiration can be delivered if BPD as the people representative is democratic and non-discriminative to the groups of people in the society

Proposition

P1: Justice and equality will invoke active participation of the community in village development

This finding confirms Yunita and Cristianingrum (2018) that when conflict of interest occurs, the community can file a report or complaint to the village through BPD or Regional Government. The report concretely elaborates the allegation of monetary misuse by the Village officials and the estimated loss in VFA or VF. When BPD fails to respond to the report, the community may express the alleged VF misuse to the Regional Government (The Regional Inspectorate). The community is expected to hold a strong and accountable evidence on the alleged Village Fund corruption; therefore, the report is forwarded to the Law Enforcement Authority for a further process.

\subsubsection{Community Active Participation}

Premise

Pa: Community active participation occurs when the community is able to partake in Village Forums

$\mathrm{Pb}$ : Village Forums is carried out well when the village community is encouraged by justice and equality values to express their aspiration

Pc: BPD receives the community aspirations and forward them to the Village Government as an act of balance consensus

Proposition 
P2: Community active participation will encourage the balance consensus as an embodiment of Village Forums

P3: Community active participation encourages the fulfillment of Good Public Governance

This finding confirms the result by Firdha and Yuwono (2018) and Yunita and Cristianingrum (2018) that Village Forums is a platform and facility for the Village Government, BPD and the community to discuss the problem solving of issues in the village related to the needs, improvement and development of village potential and assets. The researcher assumed that in ideal notion, the village community are fully involved, with the spirit of "Gotong Royong", from planning to evaluation process of village development as the embodiment of Good Public Governance. It has been stated in Article 80 Section (1) as the required participation in planning process, Article 81 Section (2) in implementation process, and Article 82 Section (5) in Village evaluation process. The process is reinforced by the legalisation of Ministry of Home Affairs Regulation No. 113 Tahun 2014, which expressed the principle of participation in Article 2 Section (1) that regulates the community involvement in VFM.

\subsubsection{Consensus Balance}

Premise

Pa: BPD has a duty to accommodate the people aspiration and to deliver the aspiration in Village Forums

$\mathrm{Pb}$ : The consensus - oriented Village Forums exists because the community rights and responsibilities to partake in village development through aspiration and action are responded by the BPD and forwarded to the Village Government

Pc: Village Forums is the platform to control whether or not to follow up the community aspiration and to acknowledge APBDesa report based on Village Regulation

Proposition

P4: Balance Consensus encourages the transparent reporting of APBDesa by the Village Government

This finding supports Azlina et al. (2017) that Village Forums is basically bridging the community interest to reach a thorough consensus. However, Simangunsong and Wicaksono (2017) argue that the different pretentions in the community may hinder the planning, implementation and management of Village Fund. To overcome this obstacle, the Village Government creates an assumption and proposes a notion on Village Government to improve the quality of Village Forums by creating a decision-making mechanism based on the priority program of community needs and encouraging the village officials to exercise transparency to the target programs of village development.

\subsubsection{Legal Aspect}

Premise

Pa: The government is to nurture the village officials' understanding on legal aspect 
$\mathrm{Pb}$ : The government perform stewardship to the village officials on legal aspect related to VFM as a form of government responsibility

Pc: VFM transparency and accountability is achieved when the village officials comprehend Village Law

Pd: The government is responsible in VFM supervision according to Village Law

Proposition

P5 The role of Village legal aspect encourages the government to perform stewardship and supervision to the village officials in supporting VFM transparency and accountability

This finding confirms Salim et al. (2017) that Village Law would contribute to the change towards a more transparent and accountable government. The law would direct the government to manage VFA and VF according to the applicable regulation, i.e. Village Law Article 26 Section (1) and Section (4) and Ministry of Home Affairs Regulation No. 113 of 2014 Article 2 Section (1). On the other hand, the law forces the village officials to undertake a complex reporting task which may lead to compromising the legal aspect in the reporting. It could happen because of the limited knowledge and skill of the village officers to make the financial statement for APBDesa. This limitation eventually leads to corruption in Village Fund.

Village Funds misuse committed by the Village officers is forbidden by the Village Law. The administrative sanctions vary from written admonition, suspension, to work termination (Village Law Article 28 Section 1 and Section 2). Moreover, if the funds misuse imposes some loss to the state, the misconduct is considered a corruption as has been stated in Law No. 31 of 1999 jo. Law No. 20 of 2001 on Eradicating Corruption Crime. Accordingly, the role of stewardship and supervision by the government is crucial to keep the Village Government free from Village funds misuse regardless the limited knowledge and skill (quality) of the village officers.

\subsubsection{Responsibility}

Premise

Pa: Community active participation exists because of government stewardship

$\mathrm{Pb}$ : Government stewardship to the community is part of the government responsibility

Pc: Siskuedes can be the agency to minimize the misuse of Village Funds by the Village Government, and to facilitate the access to village financial information

Pd: Regional Inspectorate controls VFM and the empowerment of Village Funds

Pe: Development of Village information system and the role of Regional Inspectorate are the Government duties

Proposition

P6: The government is responsible to encourage the community active participation 
P7: The government is responsible to encourage a transparent reporting of APBDesa by the Village Government

This finding confirms Ash-shidiqqi and Wibisono (2018), Fikri, Suharto and Nugroho (2018), and also Yunita and Cristianingrum (2018). It is important to conduct socialization and training that is parallel to the actual phenomena on the low quality of human resources in village i.e. the village officials to manage Village Fund (Simangunsong and Wicaksono, 2017; Firdha and Yuwono, 2018). Consequently, the role of BPMPD is very important to direct an up to par VFM by Village officials. Furthermore, BPMPD plays a role in fostering the village officials to implement Siskuedes. It indicates the government and Village Government's appreciation and sincerity to support supervision over VFM to achieve the transparency and accountability. It is in line with Fikri et al. (2018) that from 2015, the Government of Banyuwangi District has appointed Siskuedes as the media for budgeting, management and reporting. Technically, Siskuedes is the transformation of internet and e-government.

On the other hand, the village community needs stewardship though workshop on the essence of Village Law such as empowering the community with gotong-royong participation. This pattern of participation enables the Village Government to supervise VFM. Furthermore, it is in line with Yunita and Cristianingrum (2018) that control function run by the Regional Inspectorate is crucial to maintain VFM effective. Accordingly, the researcher believes that the essence of supervision is to conduct early prevention of deviance, wastefulness, fraud, hindrance, errors, and failure to reach the vision of the organization. Therefore, an effective intersectoral coordination is necessary to establish a more transparent management because a transparent government will undertake accountable programs and activities.

\subsubsection{Transparency}

Premise

Pa: A transparent Village Government is achieved due to Village Forums

$\mathrm{Pb}$ : Village Forums is the medium for the village community to supervise the use of APBDesa

Pc: A transparent Village Government is achieved due to Siskuedes as a collaboration beween the government and Village Government

Pd: Siskuedes is a system that could minimize the deviant behaviour of Village officials in VFM and encourage the offivials to be more responsible to VFM

Proposition

P8: A transparent Village Government improves the accountability of APBDesa reporting

P9: A transparent Village Government will establish a Good Public Governance

This finding confirms Yunita and Cristianingrum (2018) that the Villages that receives VFA and VF have presented the factual report on their performance. Besides reporting to BPD, the Village Government also disseminates written information in announcement board or 
Siskuedes. The information contains APBDesa realisation and accountability report. It is the form of implementing the Ministry of Home Affairs Regulation No. 113 of 2014 Article 40 Section (1) and Section (2). Accordingly, as the Village Government being transparent to disseminate information on the report of RPJM Desa, RKP Desa and APBDesa, and as the VFM reports through Village Forums or Siskuedes, the community is encouraged to support a government free from CCN. It directly impacts the accountability of reporting and the degree of good public governance.

\subsubsection{Accountability}

Premise

Pa: Understanding the legal aspect through the government stewardship would enable the village officials to record and report APBDesa according to the applicable regulation

$\mathrm{Pb}$ : Report of Village development and government administration is submitted to BPD and village community for evaluation based on the plan and objectives of Village Fund

Pc: The planning and objectives of Village Fund mainly targets the welfare and empowerment of Village community

Proposition

P10: The accountable reporting of APBDesa would establish an effective and efficient expenditure of Village Fund in village development and government administration

P11: The accountable reporting if APBDesa would meet the degree of Good Public Governance

This finding confirms Yunita and Cristianingrum (2018) that the APBDesa accountability report includes reports on income, expenditure and cost. The report format has been stated in the appendix of Ministry of Home Affairs Regulation No. 113 of 2014. Furthermore, in the report is attached a Responsibility Report on APBD realisation that elaborates fiscal of the corresponding year, a relevant Report on Village Wealth per 31st December and the format of Sectoral Program and Village Program. In addition, as required by the law, Village Government presents the report to the District Head, the Chairman of Indonesian Investment Coordinating Board (BPKPMD), BPD and the community.

\subsubsection{Effectiveness and Efficiency}

Premise

Pa: Village development and government administration are considered effective and efficient when the Village Government holds accountability in undertaking its functions and duties

$\mathrm{Pb}$ : The accountability of Village Government is measurable when the human resource, i.e. the village officials retain capability, competence and professionalism

Pc: Electing the capable, competent and professional village officials can maximize the 
utilization of natural resources

Pd: A well-utilized natural resources will lead to the improved economy and community welfare

Proposition

P12: The effective and efficient expenditure of Village Fund would affect the government attention to improve the economy and community welfare meet the degree of Good Public Governance.

This finding confirms Azlina et al. (2017) that budget wasting still occurs in Village. The village officials lack competence and professionalism could hinder in achieving the goal because of incapability to budget village expenditure according to the needs. However, this issue has been addressed with the help of Village Counsellor and regular training on recording, reporting and Siskuedes by BPMPD for the village officials.

\subsubsection{The Government Attention}

Premise

Pa: Public service is established when Village Government understand the issues in the village and the community needs

$\mathrm{Pb}$ : The essential issues in the Village and the priority of community needs are explored when the community partake in Village Forums

Pc: Village Forums encourages the Village Government to be more transparent and accountable that nurtures the community welfare as a form of Government attention

Proposition

P14: Village Forums as a platform for diverse consensus would encourage the government attention

P15: Government attention would lead to the fulfilment of Good Public Governance

This finding supports Azlina et al. (2017) that the programs and agenda for village development and community empowerment need to conform with local wisdom in each village. Local wisdom refers to budget-related policy in Village Government must be in accordance with the need and utilization of Village natural resources. Therefore, it is important that village budgeting follows the procedure from the government, i.e. through Village Forums. Village Forums will improve the transparency and accountability of Village Government because the community actively participate in disseminating aspiration or suggestion on the village current needs. A transparent and accountable Village Government will encourage government attention to prosper the community.

Furthermore, the theoretical structure is composed to establish Efficient Contracting for Village Fund management. Accordingly, the researcher proposes Ef ficient Contracting model presented in Figure 2 below: 


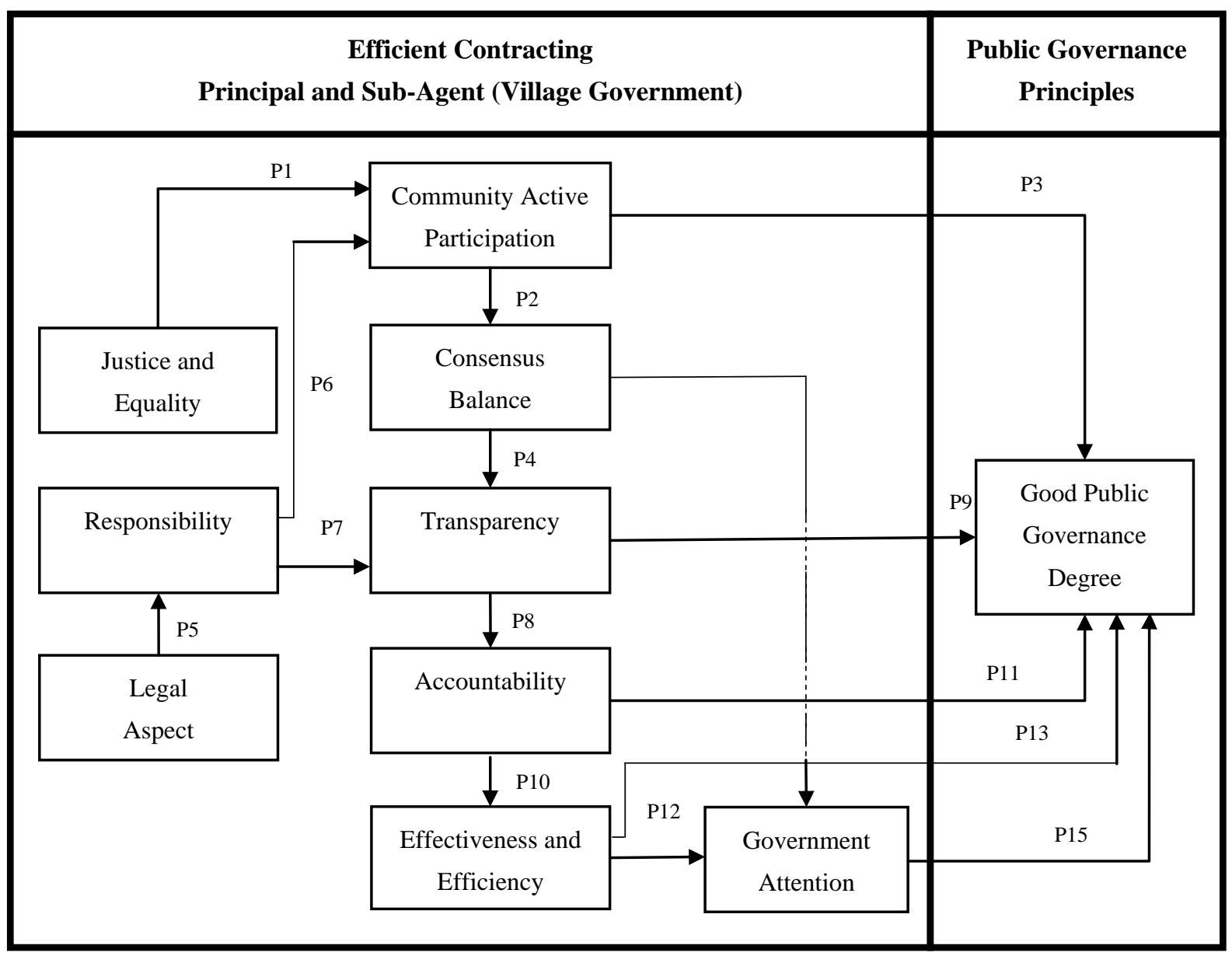

Figure 2. Efficient Contracting Model on Village Governance

The principles are contained in the 10 OECD principles as the guideline for the government to establish an open and inclusive policies. The principles include commitment, rights, clarity, inclusiveness, resources, coordination, accountability, evaluation, and active citizenship. This holistic relationship explains the essence of Efficient Contracting for village governance. The commitment principle starts from the government understanding on the legal aspect which shapes the government responsibility to reach the vision which eventually embodies the government attention. Furthermore, the rights, clarity, time and inclusiveness principles are closely related to the justice and equality variables that encourage community active participation in the government forum as a realization of consensus balance. The resources in this context refer to financial resources, human resources and technical resources that support the government administration; therefore, the resources are related to effectiveness and efficiency variables. At last, coordination, accountability and evaluation are the inseparable, fundamental aspects of the government administration to establish an open government and to direct the fulfilment of the government's vision and priority. Accordingly, the ten OECD principles conform the nine principles in this study.

\section{Contribution and Implication}

In conceptual manner, the result of this research is proposed to expand the perspective of 
public governance in village level, the concept of development administration and public management. Efficient Contracting procedure is not sufficiently analysed to explain the issues on development administration and public management faced by the Village Government. This limitation is important to explored in improving the theoretical understanding of contracting process and the result.

In practical manner, a sound understanding of the Law would enable the Village Officials to meticulously manage the Village Fund, make decision based on the community needs, direct a conducive administrative procedure which eventually improve the efficiency and quality of public service. Also, the new idea on Efficient Contracting in this study would fulfil the three pivotal points by Bourgon (2007). It enables the Government authority- the Executive and Legislative from the Central, Provincial, Regional and Village level-to exercise a deep reflection.

\section{Conclusion and Reccommendation}

Efficient Contracting for Village governance in agency theory is an emerging, intriguing formula and concept for the Village Officials and related stakeholders to undertake VFM towards the Good Public Governance. The essence of Efficient Contracting has been identified, described and elaborated extensively according to the regulation of village governance. Efficient Contracting consists of nine principles-Community Active Participation, Legal Aspect, Government Attention, Consensus Balance, Effectiveness and Efficiency, Justice and Equality, Transparency, Responsibility and Accountability. The Community Active Participant, Transparency, Accountability, Effectiveness and Efficiency and Government Attention collectively improve the degree of Good Public Governance. In addition, the Legal Aspects, Consensus Balance, Justice and Equality and Responsibility are interconnected to support the Good Public Governance.

The nine principles of Efficient Contracting, when properly and legally undertaken, would benefit the Village Officials in making realistic decisions on managing the village fund. Moreover, the application of Efficient Contracting is expected to direct the fulfillment of three pivotal points by Bourgon (2007) namely obey the law, commit to serve public interest, and encourage the Village Officials to exercise integrity, honesty, and neutrality in undertaking public duties. In defence of an argument that Efficient Contracting is in accordance with the Village Law in Indonesia, the researcher explored an extensive academic literature on the condition and issues related to VFA and VF management and discussion on "Gotong royong" pattern of participation as the ideology and culture of Republic of Indonesia that synchronizes with the articles in Village Law and Ministry of Home Affairs Regulation No. 113 of 2014.

Based on the conclusion, it is recommended that (1) the Central and Regional Government and the Legislator to investigate and disseminate the Efficient Contracting concept for Village Fund management related to VFM towards Good Public Governance; (2) the experts of Administrative Law in Regional/Village level to focus on the challenge and barriers in implementing the law and Government Regulation (the District Head) about Village Fund Management; (3) Village Government-Village Officials in particular-should conduct their 
duties and functions according to the applicable law in order to minimize the misuse of Village Fund. Accordingly, Efficient Contracting concept explicitly elaborates the correct procedure so the Village Officials and the related stakeholders undertake a sound development administration and public management.

\section{Limitation and Further Study}

The result of this study only identifies the variability of public governance but offers a practical explanation on the extent of each variability. The result enables the future researchers to identify and explore the issues to enhance the Efficient Contracting concept in public governance. Furthermore, the result of this study describes variability relationship of efficient contracting in a holistic manner using qualitative methods. Therefore, research using quantitative methods has the opportunity to test the research propositions as hypotheses.

\section{References}

\section{Articles and Books}

Adele, C., Frisie, C., \& Washburn, R. (2015). Situational Analysis in Practice (Mapping Research with Grounded Theory). Routledge Taylor \& Francis Group, London and New York.

Afifah, D., Kartini, D., \& Yuningsih, N. (2017). Village Independence In Village Funds (A Case of Village Fund Management in Traditional and Modern Villages). Advances in Social Sciences Research Journal, 4(25), 134-145.

Afonso, A., Schuknecht, L., \& Tanzi, V. (2005). Public Sector Efficiency: An International Comparison. Public Choice, 123(3-4), 321-47. https://doi.org/10.1007/s11127-005-7165-2

Akhlaghi, F. (1996). Ensuring Value for Money in FM Contract Services. Facilities, 14(1/2), 26-33. https://doi.org/10.1108/02632779610098037

Ammons, D., \& Rivenbark, W. (2008). Factors Influencing the Use of Performance Data to Improve Municipal Services: Evidence from the North Carolina Benchmarking Project. Public Administration Review, 304-318. https://doi.org/10.1111/j.1540-6210.2007.00864.x

Ash-shidiqqi, E., \& Wibisono, H. (2018). Corruption and Village: Accountability of Village Fund Management on Preventing Corruption (Problems and Challenges). Journal of Indonesian Legal Studies, 3(2), 195-212. https://doi.org/10.15294/jils.v3i02.27524

Atiyah, P. S. (1996). An Introduction to the Law Contract. Clarendon Press, Oxford.

Azlina, N., Hasan, A., \& Muda, I. (2017). The Effectiveness of Village Fund Management (Case Study at Villages in Coastal Areas in Riau). International Journal of Economic Research, 14(12), 325-336.

Battese, G. E., \& Coelli, T. J. (1995). A Model for Technical Inefficiency Effects in a Stochastic Frontier Production Function for Panel Data. Empirical Economics, 20(2), 325-332. https://doi.org/10.1007/BF01205442 
Bergen, M., Dutta, S., \& Walker, O. C. (1992). Agency Relationships in Marketing: A Review of the Implications and Applications of Agency and Related Theories. Journal of Marketing, 56(3), 1-24. https://doi.org/10.1177/002224299205600301

Bourgon, J. (2007). Responsive, Responsible, and Respected Government: Towards a New Public Administration Theory. International Review of Administrative Sciences, 73(7), 7-26. https://doi.org/10.1177/0020852307075686

Bovens, M. (2006). Analysing and Assessing Public Accountability: A Conceptual FrameWork. European Governance Papers (EUROGROV), No. 1, European Governance Papers (EUROGOV), CONNEX and EUROGOV networks.

Bowen, J. R. (1986). On the Political Construction of Tradition: Gotong Royong in Indonesia. The Association for Asian Studies, 45(3), 545-561. https://doi.org/10.2307/2056530

Boyne, G. A. (2003). Sources of Public Service Improvement: A Critical Review and Research Agenda. Journal of Public Administration Research and Theory, 13(3), 367-394. https://doi.org/10.1093/jopart/mug027

Coram, R. B. (2006). Managing Organizational Change in the Public Sector - Lessons from the privatisation of the Property Service Agency. International Journal of Public Sector Management, 14(2), 94-110. https://doi.org/10.1108/09513550110387381

Creswell, J. W. (2009). Research Design. Qualitative, Quantitative and Mixed Methods Approaches. SAGE Publication, Achmad Fawaid (2016). Research Design: Pendekatan Kualitatif, Kuantitatif dan Mixed. Edisi Kelima. Pustaka Pelajar, Yogyakarta, Indonesia.

Creswell, J. W. (2013). Qualitative Inquiry \& Research Design: Chossing Among Five Approaches. SAGE Publication, Achmad Lintang Lazuardi (2015). Penelitian Kualitatif \& Desain Riset: Memilih di antara Lima Pendekatan. Edisi Pertama. Pustaka Pelajar, Yogyakarta, Indonesia.

Fatchan, H. A. (2011). Metode Penelitian Kualitatif (Qualitative Research Method). Jenggala Pustaka Utama, Yogyakarta, Indonesia.

Fikri, H., Suharto, D. G., \& Nugroho, R. A. (2018). Utilization of Electronic Government in Realizing Transparency and Accountability of Village Government: Synergy of Implementation of Electronic Village Budgeting and Electronic Monitoring System by Banyuwangi Government. International Journal of Multicultural and Multireligious Understanding, 5(4), 453-469. https://doi.org/10.18415/ijmmu.v5i4.425

Firdha, A. P., \& Yuwono, T. (2018). Accountability Village of Government in Management of Village Allocation Fund in The Temulus Village, Mejobo District, Kudus Regency. Journal of Politic and Government Studies, 7(2), 131-140.

Gupta, R. K., \& Awasthy, R. (2015). Qualitative Research in Management. SAGE Publications India Pvt Ltd., New Delhi, India.

Hensher, D. A., Billon, A. Y., Macário, R., Preston, J., White, P., Tyson, B., \& Filho, R. D. O. 
(2007). Delivering Value for Money to Government through Efficient and Effective Public Transit Service Continuity: Some Thoughts. Transport Reviews: A Transnational Transdisciplinary Journal, 24(4), 411-448. https://doi.org/10.1080/01441640701192351

Hood, C. (1991). A Public Management For All Seasons?. Public Administration, 69(1), 3-19. https://doi.org/10.1111/j.1467-9299.1991.tb00779.x

Hood, C. (1995). Contemporary Public Management: A New Global Paradigm?. Public Policy and Administration, 10(2), 103-117. https://doi.org/10.1177/095207679501000208

Iyoha, F. O., \& Oyerinde, D. (2010). Accounting Infrastructure and Accountability in the Management of Public Expenditure in Developing Countries: A Focus on Nigeria. Critical Perspectives on Accounting, 21(5), 361-373. https://doi.org/10.1016/j.cpa.2009.06.002

Jehn, K. A. (1997). A Qualitative Analysis of Conflict Types and Dimensions in Groups Organizational. Administrative Science Quarterly, 42(3), 530-557. https://doi.org/10.2307/2393737

Jensen, C., \& Meckling, H. (1976). Theory of the Firm: Managerial Behavior, Agency Costs and Ownership Structure. Journal of Financial Economics, 3(4), 305-360. https://doi.org/10.1016/0304-405X(76)90026-X

Kraan, D. J., Trapp, L., Kostyleva, V., Tuinen, J., \& Morgner, M. (2013). Budgeting in Ukraine. OECD Journal on Budgeting, published online first. https://doi.org/10.1787/budget-12-5k4c1s8n0br0

Lane, J. (1999). Contractualism In the Public Sector. Public Management: An International Journal of Research and Theory, 1(2), 179-194. https://doi.org/10.1080/14719039900000002

Mchopa, A. (2015). Integrating Contract Management Practices Into the Achievement of Value for Money in Tanzania Public Procurement: Evidence from Selected Procuring Entities in Moshi Municipality. Journal of Public Procurement, 15(2), 129-49. https://doi.org/10.1108/JOPP-15-02-2015-B001

Ng, A., \& Loosemore, M. (2007). Risk Allocation in the Private Provision of Public Infrastructure. International Journal of Project Management, 25(1), 66-76. https://doi.org/10.1016/j.ijproman.2006.06.005

OECD. (2016). Kajian Open Government Indonesia. https://www.oecd.org/gov/open-govreview-indonesia-kajian.pdf (accessed 17 January 2019).

Rhodes, R. A. W. (1996). The New Governance: Governing without Government. Political Studies, 44(4), 652-667. https://doi.org/10.1111/j.1467-9248.1996.tb01747.x

Saldana, J. (2011). Fundamentals of Qualitative Research. Oxford University Press, Inc., New York, USA.

Salim, A., Bulan, W., Untung, B., Laksono, I., \& Brock, K. (2017). Indonesia's Village Law : Enabler or Constraint for More Accountable Governance?. Making All Voices Count Research Report, Brighton, IDS. 
Schick, A. (1998). A Contemporary Approach to Public Expenditure Management. Governance, Regulation, and Finance Division, World Bank Institute.

Simangunsong, F., \& Wicaksono, S. (2017). Evaluation of Village Fund Management in Yapen Islands Regency Papua Province (Case Study at Pasir Putih Village, South Yapen District). Open Journal of Social Sciences, 5(9), 250-268. https://doi.org/10.4236/jss.2017.59018

Stanislaus, D. R. A., \& Syamsuddin. (2017). Pemaknaan Efisiensi Belanja Daerah Dalam Interpretative Phenomenological Analysis : Sebuah Konstruksi Atas Pemufakatan Para Agen. Integritas, 3(2), 183-202. https://doi.org/10.32697/integritas.v3i2.107

Stevens, P. A. (2004). Accounting for Background Variables in Stochastic Frontier Analysis. Discussion Paper Number 239. National Institute of Economic and Social Research, London.

Stiglitz, J. E. (2003). Globalization and Its Discontents. Review of Banking, Finance and Monetary Economics, 32(2), 123-142. https://doi.org/10.1046/j.0391-5026.2003.00107.x

Taylor, S. J., Bogdan, R., \& DeVault, M. L. (2016). Introduction to Qualitative Research Methods. John Wiley \& Son, Inc., Canada.

Temenggung, Y. A. (2016). Rural Financial Management in Perspective Law No. 6 of 2014 Concerning The Village. International Journal of Social Sciences, 43(1), 42-54.

Trihatmoko, R. A., \& Susilo, Y. S. (2018). The Conceptual Framework of Indonesia Raya Incorporated (IRI): Extending Relationship between the Economic Constitution and the Roles and Functions of State Companies. Global Journal of Management and Business Research: Economics and Commerce, 18(7), 14-30.

Widodo, I. (2017). Dana Desa Dan Demokrasi Dalam Perspektif Desentralisasi Fiskal. Indonesian Political Science Review, 2(6), 65-85. https://doi.org/10.15294/jpi.v2i1.8487

Yunita, A., \& Cristianingrum. (2018). Measurement of Accountability Management of Village Funds. Integrated Journal of Business and Economics, 2(1), 99-103. https://doi.org/10.33019/ijbe.v2i1.62

\section{Government Policies and Regulations}

Law No. 31 of 1999 jo. Law No. 20 of 2001 on Eradicating Corruption Crime

Law No. 6 of 2014 on Villages

Ministry of Home Affairs Regulation No. 113 of 2014 on Village Financial Management.

Ministry of Home Affairs Regulation No. 66 of 2007 on Village Development Planning.

\section{Newspaper}

Anticorruption.org.id. 2018. Outlook for Village Funds 2018 Potential Misuse of Village Budget in the Politics Year. https://antikorupsi.org/id/news/outlook-dana-desa-2018-potensipenyalahgunaan-anggaran-desa-di-tahun-politik (accessed 20 January 2019) 


\section{Macrothink

Abbreviations and Glossary

APBD $\quad$ : Regional Budget

APBDesa : Village Budget

APBN : State Budget

BPD : Village Consultative Agency

BPMPD : Community Development and Village Governance Agency

BPKPMD : Chairman of Indonesian Investment Coordinating Board

Gotong Royong : Mutual Assistance

CCN : Corruption, Collusion, and Nepotism

MFGD : Mini Focus Group Discussion

RKP Desa : Village Government Work Plan

RPJM Desa $\quad$ : Village Medium Term Development Plan

Siskuedes : Village Financial Information System

VF : Village Fund

VFA : Village Fund Allocation

VFM : Village Financial Management

Village Law : Law No. 6 of 2014

\section{Appendix}

Appendix 1. Recapitulation of Village Fund Distribution from 2015 to 2018 (Table 1)

\begin{tabular}{|c|c|c|c|}
\hline Years & $\begin{array}{l}\text { Average Funds Per Village } \\
\text { (In Millions of IDR) }\end{array}$ & Villages Number & $\begin{array}{l}\text { Total Village Funds } \\
\text { (In Trillions of IDR) }\end{array}$ \\
\hline 2015 & 280 & 74.754 & 20,8 \\
\hline 2016 & 628 & 74.754 & 49,9 \\
\hline 2017 & 776 & 74.954 & 58,2 \\
\hline 2018 & 800 & 74.954 & 60,0 \\
\hline
\end{tabular}

Source: Ministry of Finance

Appendix 2. Form of Misuse case of Village Fund Program 2015 - 2018 (Table 2)

\begin{tabular}{l|cl}
\hline \multicolumn{1}{c}{ Form of Misuse } & Misuse Number & \multicolumn{1}{c}{ Activities Type } \\
\hline Fraud & 32 Cases & - Office supplies payment \\
Budget Misuse & 51 Cases & - Village Fund loan for personal interest, \\
& & - Office inventory purchased with Village Fund \\
& & for personal use, and
\end{tabular}




\begin{tabular}{|c|c|c|}
\hline & & $\begin{array}{l}\text { - Conspiracy in the projects financed with } \\
\text { Village Fund. }\end{array}$ \\
\hline $\begin{array}{l}\text { Illegal Levies and } \\
\text { Budget Cut }\end{array}$ & 15 Cases & $\begin{array}{l}\text { - Failure to save or report tax levies or village } \\
\text { retribution to Village Treasury or Tax Office, } \\
\text { - Village Fund Reduction by each official in } \\
\text { Sub-district and District level, and } \\
\text { - Public budget cut for the Village officials } \\
\text { interest. }\end{array}$ \\
\hline Mark Up & 14 Cases & $\begin{array}{l}\text { - Create a budget planning above the market } \\
\text { price and } \\
\text { - Marked up salary for the Village Officials. }\end{array}$ \\
\hline Total State Losses & 17 Cases & $\begin{array}{l}\text { - Fictitious business travel by the Village Chief } \\
\text { or the staff, and } \\
\text { - Create a fictitious program or project financed } \\
\text { by Village Fund. } \\
\mathbf{2 7 . 4 6} \text { billion (IDR) }\end{array}$ \\
\hline
\end{tabular}

Source: Indonesian Corruption Watch (ICW) on the website https://antikorupsi.org and previous literature.

Appendix 3. Identifying the essence of Regulation on Village Government (Table 3)

\begin{tabular}{|c|c|c|c|}
\hline No & $\begin{array}{l}\text { Contracting } \\
\text { Efficient }\end{array}$ & $\begin{array}{c}\text { Description of Law No. } 6 \\
\text { Year } 2014\end{array}$ & $\begin{array}{l}\text { Desciption of the Ministry of } \\
\text { Home Affairs Regulation No. } \\
113 \text { Tahun } 2014\end{array}$ \\
\hline 1 & $\begin{array}{l}\text { Community Active } \\
\text { Participation }\end{array}$ & $\begin{array}{c}\text { Article } 3 \\
\text { Para e } \\
\text { Article } 4 \\
\text { Para d } \\
\text { Article } 24 \\
\text { Para k } \\
\text { Article } 26 \\
\text { Section (2) Para m } \\
\text { Article } 55 \\
\text { Para c } \\
\text { Article } 68 \\
\text { Section (2) } \\
\text { Article } 73 \\
\text { Section (2) } \\
\text { Article } 78 \\
\text { Section (3) } \\
\text { Article } 80 \\
\text { Section (1) } \\
\text { Article } 81 \\
\text { Section (2) } \\
\text { Article } 82 \\
\text { Section (5) } \\
\text { Article } 85 \\
\text { Section (1) } \\
\text { Article } 88 \\
\text { Section (1) } \\
\end{array}$ & 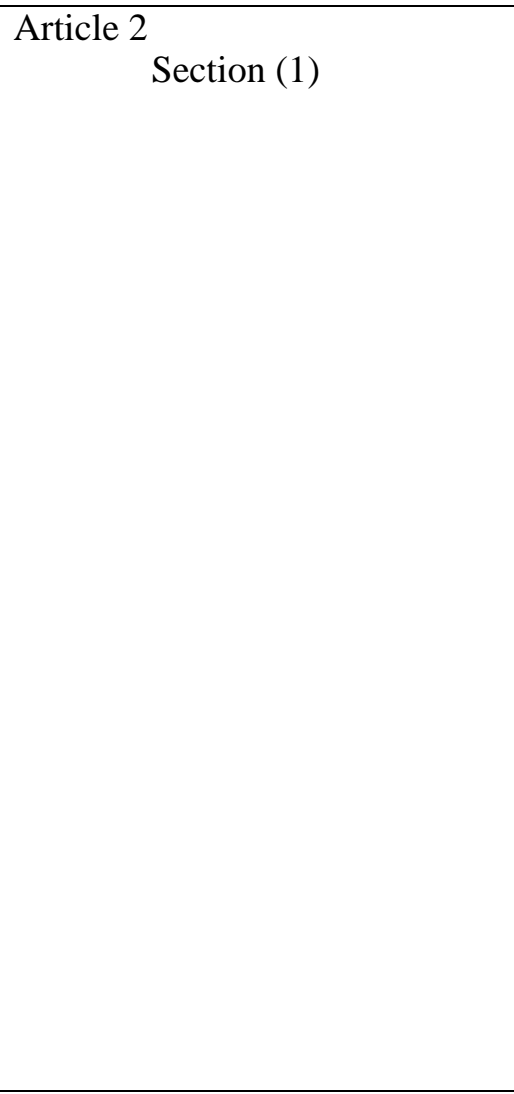 \\
\hline 2 & Legal Aspect & Article 24 & Article 2 \\
\hline
\end{tabular}




\begin{tabular}{|c|c|c|c|}
\hline & & $\begin{array}{c}\text { Para a } \\
\text { Article } 26 \\
\text { Section (4) } \\
\text { Article } 28 \\
\text { Section (1) and (2) } \\
\text { Article } 29 \\
\text { Article } 30 \\
\text { Section (1) and (2) } \\
\text { Article } 38 \\
\text { Section (3) } \\
\text { Article } 42 \\
\text { Article } 51 \\
\text { Article } 52 \\
\text { Section (1) and (2) } \\
\text { Article } 58 \\
\quad \text { Section (4) } \\
\text { Article } 72 \\
\text { Section (4) } \\
\text { Article } 77 \\
\text { Section (1) and (3) } \\
\text { Article } 79 \\
\text { Section (3) } \\
\text { Article } 84 \\
\text { Section (3) } \\
\text { Article } 117 \\
\text { Article } 119\end{array}$ & $\begin{array}{l}\text { Section (1) } \\
\text { Article } 31 \\
\text { Article } 32 \\
\text { Article } 43\end{array}$ \\
\hline 3 & $\begin{array}{l}\text { The Government } \\
\text { Attention }\end{array}$ & $\begin{array}{c}\text { Article } 3 \\
\text { Para } 1 \\
\text { Article } 4 \\
\text { Para f } \\
\text { Article } 19 \\
\text { Para b } \\
\text { Article 24 } \\
\text { Para i } \\
\text { Article } 77 \\
\text { Section (2) } \\
\text { Article } 78 \\
\text { Section (1) }\end{array}$ & $\begin{array}{l}\text { Article } 13 \\
\text { Section (1) and (2) }\end{array}$ \\
\hline 4 & Consensus Balance & $\begin{array}{l}\text { Article } 3 \\
\text { Para g } \\
\text { Article } 54 \\
\text { Section (1) and (2) } \\
\text { Article } 55 \\
\text { Para a } \\
\text { Article } 65 \\
\text { Section (1) Para c, d, } \\
\text { e and f } \\
\text { Article } 92 \\
\text { Section (2) } \\
\text { Article } 93 \\
\text { Section (2) }\end{array}$ & $\begin{array}{l}\text { Article } 20 \\
\text { Section (3) }\end{array}$ \\
\hline 5 & $\begin{array}{l}\text { Effectiveness and } \\
\text { Efficiency }\end{array}$ & $\begin{array}{l}\text { Article } 4 \\
\text { Para e } \\
\text { Article } 24 \\
\text { Para } \mathrm{h} \text { and } \mathrm{i} \\
\text { Article } 77\end{array}$ & $\begin{array}{l}\text { Article } 13 \\
\qquad \text { Section (1), (2), and (3) }\end{array}$ \\
\hline
\end{tabular}




\begin{tabular}{|c|c|c|c|}
\hline & & $\begin{array}{c}\text { Section (1) } \\
\text { Article } 81 \\
\text { Section (3) } \\
\text { Article } 85 \\
\text { Section (2) } \\
\text { Article } 86 \\
\text { Section (2) }\end{array}$ & \\
\hline 6 & Justice and Equality & $\begin{array}{c}\text { Article } 24 \\
\text { Para c } \\
\text { Article } 55 \\
\text { Para b } \\
\text { Article } 61 \\
\text { Para b } \\
\text { Article } 62 \\
\text { Article } 63 \\
\quad \text { Para b, c and d } \\
\text { Article } 68 \\
\text { Section (1) Para c } \\
\text { Article } 69 \\
\text { Section (10) } \\
\text { Article } 72 \\
\text { Section (2) } \\
\text { Article } 82 \\
\text { Section (3) }\end{array}$ & Not explained \\
\hline 7 & Transparency & $\begin{array}{c}\text { Article } 24 \\
\text { Para d } \\
\text { Article } 26 \\
\text { Section (4) Para f and } \\
\mathrm{p} \\
\text { Article } 27 \\
\text { Para c and d } \\
\text { Article } 54 \\
\text { Section (3) } \\
\text { Article } 61 \\
\quad \text { Para a } \\
\text { Article } 68 \\
\text { Section (1) Para a } \\
\text { Article } 77 \\
\text { Section (1) } \\
\text { Article } 86 \\
\text { Section (5) }\end{array}$ & $\begin{array}{l}\text { Article } 2 \\
\text { Section (1) } \\
\text { Article } 24 \\
\text { Section (3) } \\
\text { Article } 40 \\
\text { Section (1) and (2) }\end{array}$ \\
\hline 8 & Responsibility & $\begin{array}{l}\text { Article } 82 \\
\qquad \begin{array}{l}\text { Section (1), (2), (3), } \\
(4) \text { and (5) }\end{array} \\
\text { Article } 90 \\
\text { Para b } \\
\text { Article } 112 \\
\text { Article } 113 \\
\text { Article } 114 \\
\text { Article } 115\end{array}$ & $\begin{array}{l}\text { Article } 44 \\
\qquad \text { Section (1) and (2) }\end{array}$ \\
\hline 9 & Accountability & $\begin{array}{l}\text { Article } 24 \\
\text { Para g } \\
\text { Article } 26 \\
\quad \text { Section (4) Para f } \\
\text { Article } 27\end{array}$ & $\begin{array}{l}\text { Article } 2 \\
\text { Section (1) } \\
\text { Article } 20 \\
\quad \text { Section (2) } \\
\text { Article } 21\end{array}$ \\
\hline
\end{tabular}




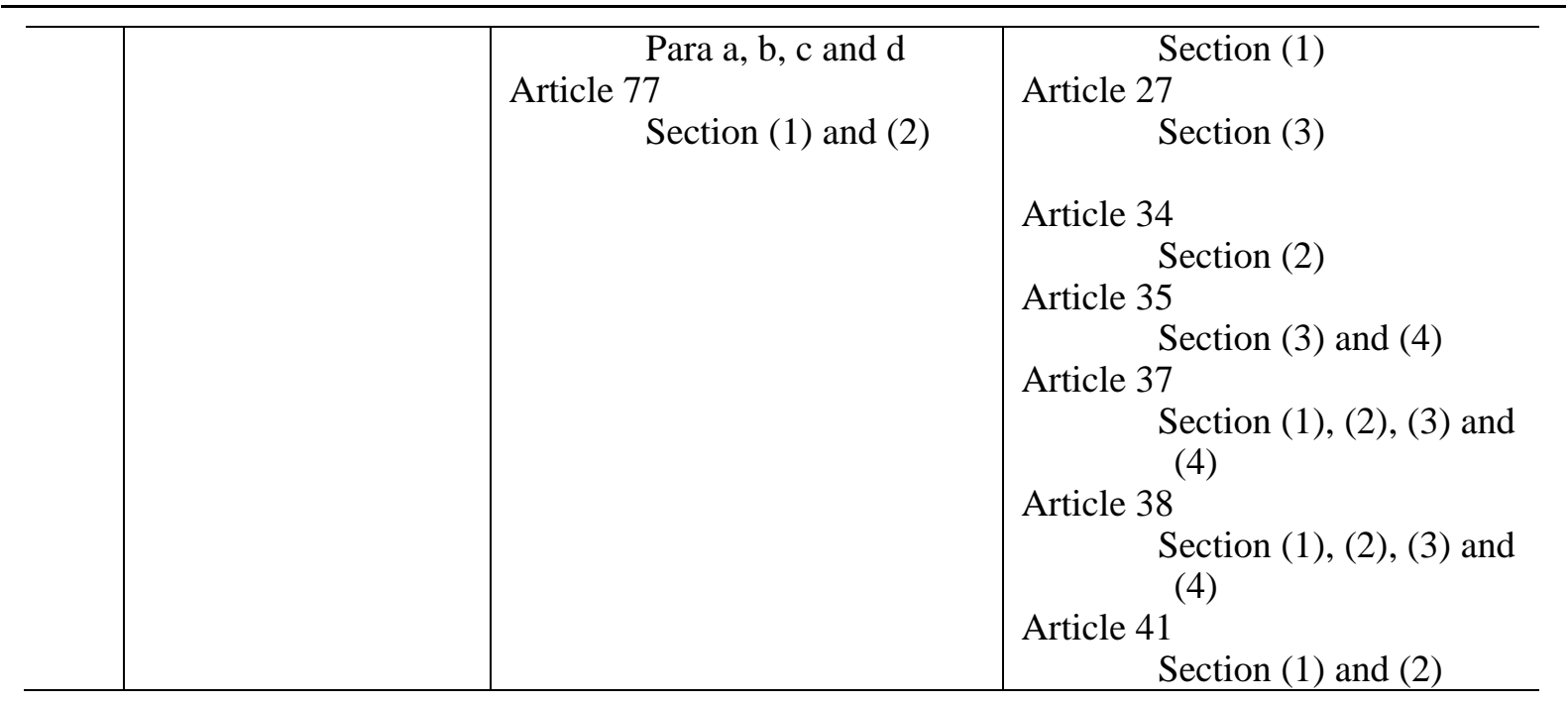

Source: Law No. 6 of 2014 through the President of Indonesian Republic decision and Minister of Home Affairs Regulation No. 113 of 2014 through the Internal Affairs Minister of Indonesian Republic decision.

Appendix 4. Increased Corruption Cases by the Village Head against Village Funds (Graph 1)

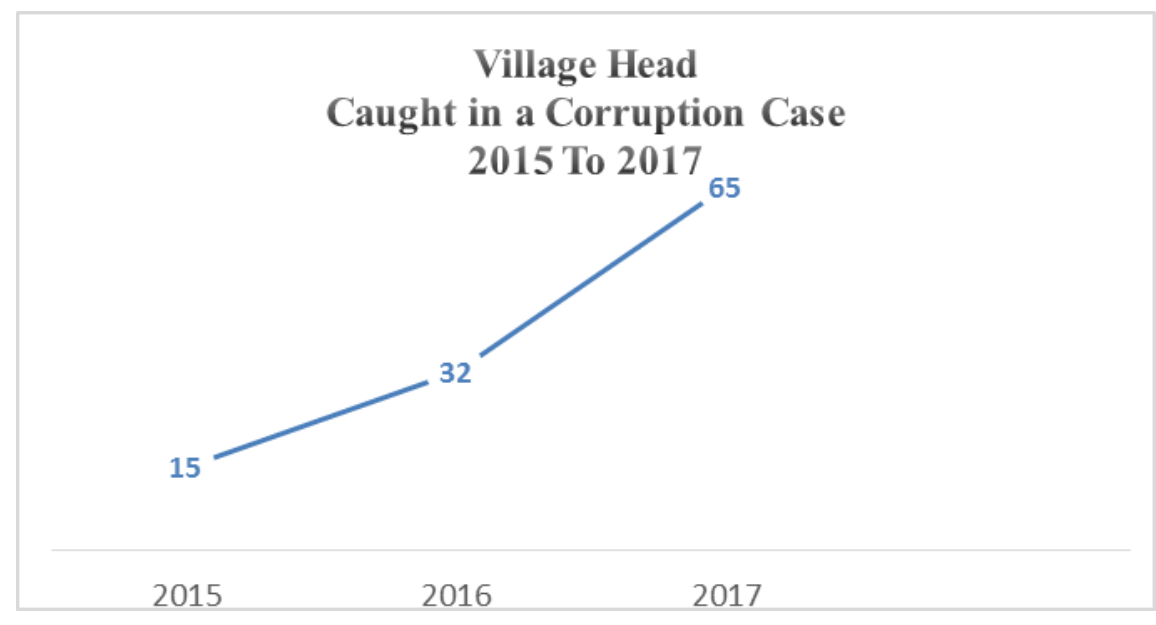

Source: Indonesian Corruption Watch (ICW) on the website https://antikorupsi.org/sites/ default/files/outlookdesa2018-icw.pdf

\section{Copyright Disclaimer}

Copyright for this article is retained by the author(s), with first publication rights granted to the journal.

This is an open-access article distributed under the terms and conditions of the Creative Commons Attribution license (http://creativecommons.org/licenses/by/4.0/). 